\title{
Pelindungan Hukum Terduga/Tersangka Tindak Pidana Terorisme Dalam Proses Penyelidikan Dan Penyidikan
}

\author{
Ramli Umar \\ Magister Hukum Fakultas Hukum Universitas Islam Indonesia Yogyakarta Indonesia \\ Jln. Cik Di Tiro No. 1 Yogyakarta Indonesia \\ ramli.umar.shmh@gmail.com
}

\begin{abstract}
This study aims to analyze first, the procedure of examination and investigation of the Crime of Terrorism. Second, the regulation and implementation of legal protection against presumed and suspects of criminal acts of terrorism in the process of examination and investigating criminal acts of terrorism. This research using juridical methods concludes that the procedure for investigation and investigation of criminal acts of terrorism is carried out based on the Criminal Procedure Code and Law Number 5 of 2018 concerning Terrorism and other related regulations. The law enforcement model in the process of investigating terrorism criminals is more likely to use a crime control model system where law enforcement is given wider and more lax authority in obtaining preliminary evidence. The prosecution process is more likely to use the due process model system. The reason it is more inclined to the due process model is because the prosecution process in terrorism cases is not specifically regulated and follows the guidelines set out in the Criminal Procedure Code.
\end{abstract}

Key Words: Crime of terrorism; examination; investigation; legal protection

\begin{abstract}
Abstrak
Penelitian ini bertujuan untuk menganalisis pertama, prosedur penyelidikan dan penyidikan terhadap Tindak Pidana Terorisme. Kedua, pengaturan dan pelaksanaan pelindungan hukum terhadap terduga dan tersangka tindak pidana terorisme dalam proses penyelidikan dan proses Penyidikan Tindak Pidana Terorisme. Penelitian dengan metode yuridis ini menyimpulkan bahwa prosedur penyelidikan dan penyidikan terhadap tindak pidana terorisme dilaksanakan berdasarkan KUHAP dan Undangundang Nomor 5 Tahun 2018 tentang Terorisme dan aturan terkait lainnya. Model penegakan hukum dalam proses penyelidikan terhadap pelaku tindak pidana terorisme lebih cenderung menggunakan sistem crime control model dimana penegak hukum diberi kewenangan yang lebih luas dan lebih longgar dalam memperoleh bukti permulaan. Proses penuntutan lebih cenderung pada penggunaan sistem due process model. Alasan lebih cenderung pada due process model adalah karena proses penuntutan dalam kasus terorisme tidak diatur secara khusus dan mengikuti pedoman yang di atur dalam KUHAP.
\end{abstract}

Kata-kata Kunci: Pelindungan hukum; pidana terorisme; penyelidikan; penyidikan 


\section{Pendahuluan}

Isu terorisme telah menjadi isu global. Kejahatan terorisme merupakan kejahatan transnasional, sehingga dibutuhkan kerjasama dari berbagai negera. Di Indonesia, aksi terror yang banyak menelan korban jiwa yaitu tragedi bom Bali I. Bom Bali I inipun telah menelan ratusan korban jiwa. Merespon tindakan terror Bom Bali I, akhirnya pemerintah mengeluarkan Perpu Nomor I Tahun 2002 untuk mengisi "kekosongan hukum" terhadap perbuatan yang dianggap sebagai ekstra ordinary crime tersebut. Setahun kemudian Perpu tersebut disahkan menjadi UU Nomor 15 Tahun 2003 tentang Pencegahan dan Pemberantasan Tindak Pidana Terorisme lalu diubah menjadi Undang-Undang Nomor 5 Tahun 2018.

Terlepas dari polemik keluarnya UU tersebut, dengan dasar UU, Densus 88 yang diberi wewenang berdasarkan Skep Kapolri No. 30/VI/2003 tertanggal 20 Juni 2003 untuk melakukan penindakkan telah banyak menangkap dan membawa terduga/tersangka terorisme ke Pengadilan. Ada yang dihukum mati, ada pula yang dihukum seumur hidup, dan ada pula yang dihukum 5 tahun sesuai perannya masing-masing. Dengan dasar UU itu pula, Densus 88 telah melakukan ekstra judicial killing terhadap banyak orang. Sejak adanya UU tersebut, sejak 2003-2017 telah menelan korban 121 orang. Dengan dasar UU itu juga, Densus 88 telah menangkap beberapa orang terduga teroris, bahkan mereka mengalami berbagai kekerasan. Dan diantara mereka yang telah dianiaya tersebut dilepaskan tanpa konpensasi, tanpa rehabilitasi.

Meskipun sudah banyak terduga menjadi korban kebiadaban aparat atas nama penegakan hukum, aparat seakan mendapatkan pembenaran dari masyarakat dan masyarakat juga menganggap proses yang inkonstitusional tersebut menjadi hal yang wajar. Kasus penangkapan yang berujung kematian yang mendapat perhatian publik cukup serius yaitu kematian terduga teroris Siyono di Klaten 4 tahun silam. Dia ditangkap tidak sesuai dengan hukum acara yang berlaku, tanpa surat perintah penangkapan dan penangkapan terduga teroris Muhammad Zufri di Jawa Barat yang meninggal di tangan Densus 88, namun Densus 88 membantah bahwa dia meninggal karena serangan jantung.

Menurut Busyro Muqoddas, sejak terbitnya Perpu Nomor 1 Tahun 2002 lalu disahkan menjadi UU Nomor 15 Tahun 2003 tentang Pencegahan dan Pemberantasan Tindak Pidana Terorisme lalu diubah menjadi Undang-Undang Nomor 5 Tahun 2018 tersebut, terdapat 120 terduga yang harus meregang nyawa 
pada proses penyelidikan dan penyidikan, ${ }^{1}$ hal ini tentu membuat publik geram karena status mereka masih "terduga", belum menjadi tersangka.

Pasal 25 kurang memberikan pelindungan hukum pada terduga. Penulis sampaikan bahwa status terduga tentu berbeda dengan tersangka, namun dalam praktik penahanan penyidik memperlakukan terduga layaknya seorang tersangka. Pasal 25 ayat (2) dikatakan untuk kepentingan penyidikan, penyidik berwenang melakukan penahanan terhadap tersangka dalam jangka waktu paling lama 120 hari. Ayat (3) jangka waktu penahanan sebagaimana dimaksud pada ayat (2) dapat diajukan permohonan perpanjangan oleh penyidik kepada penuntut umum untuk jangka waktu paling lama 60 hari.

Selama 180 hari seorang terduga tidak memiliki pelindungan hukum dan stsatus yang jelas. Karena bisa jadi, terduga akan dibebaskan jika penyidik dalam proses penyidikan tidak memiliki minimal dua alat bukti. Hal ini dapat dibuktikan dengan adanya terduga yang sudah terlanjur ditahan oleh penyidik dan tentunya mengalami berbagai siksaan, lalu dibebaskan karena kurang bukti. Disinilah perlunya pelindungan hukum agar penyidik yang melanggar ketentuan Pasal 25 tersebut dapat dimintai pertanggungjawaban pidana sebagaimana bunyi Pasal 25 ayat (8): "setiap penyidik yang melanggar ketentuan pasal sebagaimana yang dimaksud pada ayat 7 (menjunjung tinggi HAM; tidak menyiksa terduga dipidana sesuai ketentuan peraturan perundang-undangan."

Mengkaji pelindungan hukum terhadap terduga teroris menjadi penting untuk dilakukan mengingat, proses penangkapan dan penyiksaan yang dilakukan oleh penyidik sering kali terjadi. Ternyata sudah begitu banyak orang yang baru diduga melakukan tindakan teror ditangkap dan ditahan selama 7 × 24 jam² $^{2}, 14$ hari $^{3}$, selama masa penahan tersebut, terduga mengalami berbagai penyiksaan. Dalam kondisi tangan diborgol ke belakang dan mata tertutup, terduga dipukul, ditendang, diludahi, dicaci maki, bahkan ada yang kukunya dicabut setelah direndam dengan air keras. Bahkan salah satu pengakuan mantan napi teroris yang penulis wawancarai, bercerita ditendang, dipukul, dicaci maki dan kemaluannya pun digosok balsem. Semua bentuk penyiksaan tersebut dilakukan oleh penyidik demi memperoleh keterangan/infromasi dari terduga.

Di sinilah penting adanya pelindungan hukum terhadap seorang yang baru diduga melakukann tindakann teror, karena banyak kasus terjadi, informasi yang

\footnotetext{
${ }^{1}$ Busyro Muqoddas dalam acara Indonesia Lamyer Club TV One dengan Judul "ISIS sudah di Kampung Melayu?", Juni 2017.

${ }^{2}$ Hasil wawancara dengan mantan Napi Terorisme dalam kasus Bom Bali I.

3 Hasil wawancara dengan mantan Napi Terorisme yang dihukum karena terbukti menyembunyikan bahan peledak sebanyak 1 ton di rumahnya Semrang, Jawa Tengah.
} 
diperoleh dari intelijen ${ }^{4}$ tingkat akurasinya kurang bisa dipertanggungjawabkan secara hukum. Hal ini dibuktikan dengan penangkapan yang dilakukan terhadap terduga lalu ditahan selama berhari-hari lalu dilepas karena kurangnya bukti. Sungguh ironis, seseorang yang terlanjur ditangkap dan ditahan yang tentunya tidak lepas dari berbagai penyiksaan, lalu dilepas yang jarang disertai permintaan maaf dan kompensasi terhadap korban salah tangkap tersebut.

Dari latar belakang tersebut, penulis tertarik untuk melakukan penelitian yang berkaitan dengan hak-hak terduga atau tersangka teroris dalam proses penyelidikan dan penyidikan.

\section{Rumusan Masalah}

Ada dua hal yang penulis bahas dalam penelitian ini sebagaimana rumusan masalah berikut, yaitu: pertama, bagaimana prosedur penyelidikan dan penyidikan terhadap tindak pidana terorisme? Kedua, apakah pengaturan dan pelaksanaan pelindungan hukum terhadap terduga dan tersangka tindak pidana terorisme dalam proses penyelidikan dan proses Penyidikan sudah sesuai dengan peraturan yang berlaku?

\section{Tujuan Penelitian}

Berdasarkan uraian dalam latar belakang dan permasalahan yang telah di rumuskan, maka tujuan dari penelitian ini adalah: pertama, untuk mengetahui dan mengkaji prosedur penyelidikan dan penyidikan terhadap tindak pidana terorisme; kedua, untuk mengetahui dan mengkaji pengaturan dan pelaksanaan pelindungan hukum terhadap terduga dan tersangka tindak pidana terorisme dalam proses penyelidikan dan proses penyidikan tindak pidana terorisme.

\section{Metode penelitian}

Metode penelitian yang dipakai adalah metode penelitian hukum yuridisnormatif. Pendekatan ini digunakan karena masalah yang akan dibahas berkaitan dengan tingkah laku dari aparat Penyidik dalam pelaksanaan penangkapan dan penyelidikan itu sendiri. Sifat penelitian dalam tulisan ini adalah bersifat dekriptif analitis. Karena metode penelitian adalah Normatif-empiri, maka data yang dianalisis adalah yang terdiri dari bahan hukum primer, sekunder, dan tersier. Selain itu, penulis juga menggunakan hasil wawancara dengan narasumber untuk menjelaskan topik ini.

4 Pasal 26 ayat (1) UU No. 5 Tahun 2018 perubahan atas UU No. 15 Tahun 2003 tentang Pemberantasan Tindak Pidana Terorisme memerintahkan agar informasi dari intelijen tersebut hari terlebih dahulu dilakukan veifikasi kepada ketua pengadilan negeri setempat. 


\section{Hasil Penelitian dan Pembahasan}

\section{Prosedur Penyelidikan dan Penyidikan Terhadap Tindak Pidana Terorisme}

KUHAP hadir menggantikan Het Heriziene Inlandsch Reglement (HIR) sebagai payung hukum acara pidana di Indonesia. Jika ditilik dari semangat pembentukannya, pada awalnya KUHAP lahir dengan semangat untuk mengangkat dan menempatkan tersangka atau terdakwa dalam kedudukan yang sama di depan hukum melalui jaminan pelindungan hak asasi manusia dan hakhak tersangka atau terdakwa yang sebelumnya kurang diakomodir dalam HIR. ${ }^{5}$

Undang-Undang Nomor 5 Tahun 2018 tentang Pemberantasan Tindak Pidana Terorisme menyebutkan bahwa hukum acara penindakan terhadap pelaku Tindak Pidana Terorisme mengnduk pada KUHAP kecuali ditentukan lain oleh Undang-Undang Nomor 5 Tahun 2018 tersebut. Dalam KUHAP terdapat benyak pasal yang membicarakan tentang hak-hak tersangka, antara lain: Pasal 18 ayat (1), Pasal 18 ayat (1) dan (3), Pasal 51, Pasal 52 dan 117, Pasal 54, 55, 56, 114. Sedangkan hak-hak tersangka atau terdakwa Tindak Pidana Terorisme menurut UU No. 5 Tahun 2018 tentang Pemberantasan Tindak Pidan Terorisme terdapat dalam Pasal 25 ayat (1), Pasal 25 ayat (1) sampai (6), Pasal 28 ayat (3).

Selain itu, hak-hak terduga dan tersangka dapat dijumpai dalam Perkap Nomor 23 Tahun 2011 tentang Prosedur penindakan tersangka tindak pidana terorisme dapat dijumpai dalam Pasal 3, Pasal 7, Pasal 19 angka 1, Pasal 19 ayat (3). Hak-hak yang diberikan KUHAP, undang-undang tentang Terorisme dan Perkap tentang Prosedur Penanganan Tindak Pidana Terorisme sudah memadai, tinggal pelaksanaan di lapangan, aparat mau menegakkan aturan itu atau justru malah mengesampaingkannya. Dengan substansi hukum yang ada berkaitan pemenuhan hak-hak tersangka sudah mencukupi, agar tidak diperlakukan secara semena-mena oleh penyelidik dan penyidik. Sekarang tinggal bagaimana perlakukan aparat terhadap tersangka atau terdakwa ketika melakukan proses penyelidikan dan penyidikan.

Pengaturan dan Pelaksanaan Pelindungan Hukum Terhadap Terduga dan Tersangka Tindak Pidana Terorisme dalam Proses Penyelidikan dan Penyidikan

Penyelidikan dan penyidikan tidak dapat dipisahkan karena penyelidikan bukan tindakan yang berdiri sendiri terpisah dari fungsi penyidikan. Jadi

${ }^{5}$ Aristo Pangaribuan et.al, Pengantar Hukum Acara Pidana di Indonesia, Cetakan Kedua, Rajawali Pers, Depok, 2018, hlm. 197 
menurut Pasal 1 angka 5 KUHAP penyelidikan adalah tindakan atas nama hukum untuk melakukan penelitian apakah perkara dimaksud benar-benar merupakan peristiwa pelanggaran tindak pidana atau bukan pelanggaran tindak pidana. Upaya itu adalah upaya untuk mengidentifikasi apakah sebuah peristiwa itu tindak pidana atau bukan. penyelidikan dalam kasus terorisme berarti serangkaian tindakan mencari dan menemukan suatu keadaan atau peristiwa yang berhubungan dengan terorisme atau yang diduga sebagai aksi terorisme, pencarian dan usaha menemuka peristiwanyang diduga sebagai terorisme. ${ }^{6}$ Salah satu ketentuan khusus dalam Undang-Undang tindak pidana terorisme dalam masalah penyelidikan adalah keterlibatan lembaga non-judicial yakni penggunaan laporan intelejen dalam memperoleh bukti permulaan yang cukup untuk dijadikan menetapkan seseorang jadi tersangka sehingga dapat dilakukan penangkapan, penahanan, penyadapan, penggeledahan dan penyitaan.

Jika dilihat dari rumusan Pasal 26 ayat (4) maka laporan intelejen didudukan sebagai bukti pokok. Artinya laporan intelejen dapat menjadi bukti untuk memperoleh bukti permulaan yang cukup tanpa dibutuhkan bukti lainnya sehingga dapat menjadi dasar dapat dilakukannya penyidikan. ${ }^{7}$

Pasal 1 butir 1 dan 2 merumuskan bahwa pengertian penyidik adalah pejabat polri atau pegawai negeri yang diberi kewenangan khusus oleh UndangUndang. Sedangkan penyidikan berarti serangkai tindakan yang dilakukan oleh pejabat penyidik sesuai dengan cara yang diatur oleh Undang-Undang untuk mencari serta mengumpulkan bukti dan dengan bukti membuat dan menjadi terangnya tindak pidana yang terjadi sekaligus menemukan tersangkanya atau pelaku. ${ }^{8}$ Ketika membicarakan ketentuan khusus proses penyidikan dalam ketentuan Undang-Undang pemberantasan tindak pidana terorisme maka akan sangat berkaitan dengan penyelidikan yang menggunakan laporan intelijen akan berkaitan dalam prose selanjutnya seperti penyidikan penangkapan penahanan. Maka kembali kepada laporan intelejen dapat dikatakan bahwa dalam proses penyidikan apatur negara lebih condong pada sistem crime control model. Itu artinya penegak hukum telah diberikan kekuasaan yang lebih longgar dalam melakukan proses pidana terorisme.

Di dalam proses penyelidikan dan penyidikan tindak pidana terorisme, penyidik sering malukan tindakan penyiksaan terhadap seorang yang diduga sebagai pelaku teror, sebagai contoh terduga teroris Siyono yang meninggal saat

${ }^{6}$ Abdul Wahid, Sunardi dan Muhammdad Imam Sidiq, Kejahatan Terorisme Persepektif Agama, Ham dan Hukum, PT. Raflika Aditama, Bandung, 2004, hlm 104.

7 Ari Wibowo, Hukum Pidana Terorisme, Graha Ilmu, Yogyakarta, 2012, hlm 154.

8 M. Yahya Harahap, Pembahasan Permasalahan dan Penerapan KUHAP (Pemeriksaan Pengadilan, Banding, Kasasi, dan Peninjauan Kembali), Jakarta, Sinar Grafika, 2009, hlm. 111. 
proses penyelidikan dan penyidikan. ${ }^{9}$ Dan yang perlu dicatat juga bahwa lahirnya undang-undang teorisme di Indonesia tidak lepas dari pengaruh dan intervensi Amerika dan Australia, sehingga perlu mawas diri agar tidak ada agenda terselubung dalam proses penegakan hukum terhadap terduga dan tersangka teroris. ${ }^{10}$

Melihat proses penangkapan dan penyiksaan yang berujung pada kematian seorang terduga yang telah penulis sampaikan pada bab sebelumnya, seakanakan penyiksaan sebagai suatu perilaku yang terintegrasi dalam sistem peradilan sidana di Indonesia khususnya dalam proses penyelidikan dan penyidikan terhadap terduga atau tersangka terorisme.

Pelanggaran hukum dalam kasus Siyono sudah dilakukan penyidik dengan tidak adanya surat perintah penangkapan, penggeledahan dan penyitaan. Jika merujuk pada aturan yang ada bahwa penangkapan, penahanan, penggeledahan, dan penyitaan harus berdasarkan perintah tertulis dari pejabat yang diberi wewenang oleh undang-undang dan hanya menurut cara yang diatur oleh undangundang. Pasal 18 ayat (1) Undang-Undang No. 8 Tahun 1981 tentang Kitab UndangUndang Hukum Acara Pidana (KUHAP) berbunyi: "Pelaksanaan tugas penangkapan. dilakukan oleh petugas kepolisian negara Republik Indonesia dengan memperlihatkan surat tugas serta memberikan kepada tersangka surat perintah penangkapan yang mencantumkan identitas tersangka dan menyebutkan alasan penangkapan serta uraian singkat perkara kejahatan yang dipersangkakan serta tempat ia diperiksa".

Menurut Mudzakkir, perlakuan aparat seperti ini tidak bedanya dengan tindakan premanisme. Disebut aparat karena saat melakukan suatu tindakanapalagi penegakkan hukum-berpedoman pada aturan yang ada, sedangkan sebutan premanisme dilekatkan pada sebuah tindakan orang yang tidak memiliki aturan main yang jelas.

Pelanggaran lain yang diperlihatkan oleh penyidik adalah terduga Siyono ditangkap di masjid saat sholat maghrib. Penyidik memang diberi wewenang penuh oleh undang-undang untuk melakukan penangkapan terhadap seorang yang diduga melakukan tindak pidana terorisme, di sisi yang lain kewanangan itu juga dibatasi oleh aturan yang lain, misalnya dalam hukum acara pidana menyebutkan bahwa ada beberapa tempat yang tidak bisa dimasuki oleh penyidik, kecuali dalam hal tertangkap tangan. Pasal 35 Kitab Undang-Undang Hukum Acara Pidana (KUHAP) berbunyi: yaitu: ruang di mana sedang berlangsung sidang Majelis Permusyawaratan Rakyat, Dewan Perwakilan Rakyat

${ }^{9}$ Diolah dari Shofwan AL Banna, Membentangkan Ketakutan, Cetakan Pertama, Pro-U Media, Yogyakarta, 2011, hlm. 151-161.

10 Ruslan Renggong, Hukum Pidana Khusus; Memahami Delik-Delik Di Luar KUHP, Cetakan Ketiga, Prenemedia Grup, Jakarta, 2019, hlm. 104. 
atau Dewan Perwakilan Rakyat Daerah, tempat di mana sedang berlangsung ibadah dan atau upacara keagamaan, ruang dimana sedang berlangsung sidang pengadilan.

Pada kasus Siyono, selain pelanggaran administrasi, pelanggaran pidana juga dilakukan oleh penyelidik dan penyidik Tindak Pidana Terorisme. Pelanggaran pidananya berupa penyiksaan yang berakhir pada hilangnya nyawa terduga. Pelaku dapat dipidan dengan Undang-Undang Nomor 5 Tahun 1998 tentang Pengesahan Konvensi Menentang Penyiksaan dan Perlakuan atau Penghukuman yang Kejam Tidak Manusiawi atau Merendahkan Martabat Manusia. Selanjutnya hak untuk bebas dari penyiksaan diatur secara langsung oleh konstitusi melalui perubahan kedua Undang-Undang Dasar 1945. Berdasarkan Pasal 28G ayat (2), yaitu: "setiap orang berhak untuk bebas dari penyiksaan, atau perlakuan yang merendahkan derajat dan martabat manusia dan berhak memperoleh suaka politik dari negara lain."

Berdasarkan hasil wawancara diketahui bahwa terduga teroris yang lain mendapatkan penyiksaan sebagaimana hasil wawancara berikut: "kami ditahan diruangan tersebut selama tujuh hari dan selama tujuh hari itu kami disiksa tiada henti demi mendapatkan informasi ... siksaannya benar-benar diluar batas perikemnusiaan. bahkan densus 88 ada yang menantang, mana tuhanmu, yang akan membelamu?"

Informan lainnya juga memberikan keterangan yang sama sebagaimana kutipan wawancara berikut: "Mulai dari proses penangkapan kemudian penahanan di ruangan tertentu kami dikumpulkan secara bersama-sama dengan tersangka ataupun terduga lainnya kemudian disitu kami di introgasi, disiksa dengan pukulan, bentakan dan segala macam bentuk siksaan lainnya selama tiga hari. Lalu kami dibawa ke Polda Jawa Tengah untuk di BAP. Keberadaan kami selama tiga hari tidak diketahui oleh keluarga."

Berdasarkan kutipan wawancara dapat diketahui bahwa tersangka diperlakukan tanpa memandang hak asasinya sebagai manusia. Disinilah perlunya pelindungan hukum agar penyelidik dan penyidik yang melanggar ketentuan Pasal 25 tersebut dapat dimintai pertanggungjawaban pidana sebagaimana bunyi Pasal 25 ayat (8): "setiap penyelidik dan juga penyidik yang melanggar ketentuan pasal sebagaimana yang dimaksud pada ayat 7 (menjunjung tinggi HAM; tidak menyiksa terduga dipidana sesuai ketentuan peraturan perundang-undangan."

Perlu dicatat bahwa orang yang diduga melakukan tindak pidana, masih berstatus terduga. Menurut Mudzakkir, status terduga harus disamakan dengan status orang pada umumnya, dia belum tersangka. Setelah proses penyelidikan dan menemukan bukti baru dinaikkan menjadi tersangka, maka disinilah pelindungan hukum terhadap terduga teroris menjadi penting untuk dilakukan nmengingat, proses penangkapan dan penyiksaan yang dilakukan oleh penyelidik dan juga penyidik sering kali terjadi. 
Di sinilah penting adanya pelindungan hukum terhadap seorang yang baru diduga melakukann tindakan teror, karena banyak kasus terjadi, informasi yang diperoleh dari intelijen ${ }^{11}$ tingkat akurasinya kurang bisa dipertanggungjawabkan secara hukum. Hal ini dibuktikan dengan penangkapan yang dilakukan terhadap terduga lalu ditahan selama behari-hari lalu dilepas karena kurangnya bukti. Sungguh ironis, seseorang yang terlanjur ditangkap dan ditahan yang tentunya tidak lepas dari berbagai penyiksaan, lalu dilepas yang jarang disertai permintaan maaf dan kompensasi terhadap korban salah tangkap tersebut.

Meskipun pada Pasal 26 ayat (1) dan (2) yang mengharuskan data intelijen tersebut harus dilakukan verifikasi terlebih dahulu oleh Ketua Pengadilan Negeri dalam wilayah hukum penyidik, namun dalam praktiknya perintah melakukan verifikasi tersebut jarang dilakukan: "Selama saya bertugas di Pengadilan Negeri Sukoharjo, belum pernah kami mendapatkan permohonan melakukan verifikasi informasi intelijen pada ketua Pengadilan Negari Sukoharjo. Walaupun undang-undang memerintahkan demikian, namun faktanya kami belum pernah menangni masalah ini."12

Jawaban yang sama disampaikan oleh Gandung saat penulis wawancarai: "meskipun banyak terduga teroris yang ditangkap di wilayah hukum pengadilan negeri Klaten, namun kami belum pernah didatangi penyidik untuk melakukan verifikasi informasi intelijen ataupun izin penyitaan dan penggledahan saat melakukan penyelidikan dan penyidikan."13

Menurut Mudzakkir, konsekuensi logis dari proses penangkapan dan penyiksaan dan bahkan sampai pada ekstra judicial killing adalah pertanggungjawaban pidana yang dibebankan pada penyelidik dan penyidik yang melakukan penyidikan. Meminta pertanggungjawaban pidana terhadap Densus 88 dan penyelidik dan penyidik perlu dilakukan mengingat sudah begitu banyak kasus terduga yang mengalami penyiksaan lalu dilepas atau bahkan ada yang disiksa sampai mati seperti yang dialami Siyono di Klaten pada 2016 silam dan Muhammad Jufri di Jawa Barat. Kedunya meregang nyawa masih pada proses penyelidikan, artinya bisa jadi mereka tidak bersalah karena berpedoman pada asas praduga tak bersalah.

Pasal 104 Undang-Undang Nomor 39 Tahun 1999 menyatakan bahwa pelanggaran HAM berat ialah pembunuhan sewenang-wenang atau di luar putusan pengadilan (extra judicial killing, penyiksaan, penghilangan orang secara

11 Pasal 26 ayat 1 UU No. 5 Tahun 2018 perubahan atas UU No. 15 Tahun 2003 tentang Pemberantasan Tindak Pidana Terorisme memerintahkan agar informasi dari intelijen tersebut hari terlebih dahulu dilakukan verifikasi kepada ketua pengadilan negeri setempat.

12 Wawancara dengan Bogi Agus Santoso, Bagian Humas dan Hakim di Pengadilan Negeri Sukoharjo. Selasa, 12 Januari 2021.

13 Wawancara dengan hakim Gandung, Hakim Pengadilan Negeri Klaten, Jawa Tengah. Kamis, 14 Januari 2021. 
paksa). Adapun bunyi pasal tersebut bahwa setiap orang yang ditangkap, ditahan, dituntut karena disangka melakukan suatu tindak pidana berhak dianggap tidak bersalah sampai dibuktikan kesalahannya secara sah dalam suatu persidangan dan diberikan segala jaminan hukum yang diperlukan untuk pembelaan.

Selain itu, kitab undang-undang hukum pidana bisa diterapkan kepada anggota Densus 88 yang terbukti melakukan kejahatan, baik berupa penyiksaan maupun penyiksaan sampai menyebabkan matinya terduga atu tersangka, yaitu Pasal 422 disebutkan "seorang pejabat yang dalam suatu perkara pidana menggunakan sarana paksaan, baik untuk memeras pengakuan, maupun untuk mendapatkan keterangan, diancam dengan pidana penjara paling lama empat tahun.

\section{Penutup}

Penelitian ini menyimpulkan bahwa pertama, prosedur penyelidikan dan penyidikan terhadap tindak pidana terorisme dilaksanakan berdasarkan KUHAP dan Undang-Undang Nomor 5 Tahun 2018 tentang Terorisme dan aturan terkait lainnya. Model penegakan hukum dalam proses penyelidikan terhadap pelaku tindak pidana terorisme lebih cenderung menggunakan sistem crime control model dimana penegak hukum diberi kewenangan yang lebih luas dan lebih longgar dalam memperoleh bukti permulaan. Proses penuntutan lebih cenderung pada penggunaan sistem due process model. Alasan lebih cenderung pada due process model adalah karena proses penuntutan dalam kasus terorisme tidak diatur secara khusus dan mengikuti pedoman yang di atur dalam KUHAP.

Kedua, pengaturan dan pelaksanaan pelindungan hukum terhadap terduga dan tersangka tindak pidana terorisme dalam proses penyelidikan dan proses Penyidikan Tindak Pidana Terorisme dilaksanakan berdasarkan KUHAP, Perkap No. 6 Tahun 2019 Tentang Penyidikan Tindak Pidana, Undang-undang Nomor 39 Tahun 1999 tentang Hak Asasi Manusia, dan Undang-Undang Nomor 5 Tahun 2018 tentang Terorisme. Meskipun demikian hak-hak yang diberikan undangundang tentang Terorisme dan Perkap tentang Prosedur Penanganan Tindak Pidana Terorisme sudah memadai, tinggal pelaksanaan di lapangan, aparat mau menegakkan aturan itu atau justru malah mengesampingkannya.

\section{Daftar Pustaka}

\section{Buku}

Aristo, Pangaribuan, et.al, Pengantar Hukum Acara Pidana di Indonesia, Cetakan Kedua, Rajawali Pers, Depok, 2018.

AlBanna, Shofwan, Membentangkan Ketakutan, Cetakan Pertama, Pro-U Media, Yogyakarta, 2011. 
Harahap, M. Yahya, Pembahasan Permasalahan dan Penerapan KUHAP (Pemeriksaan Pengadilan, Banding, Kasasi, dan Peninjauan Kembali, Sinar Grafika, Jakarta, 2009.

Renggong, Ruslan, Hukum Pidana Khusus; memahami delik-delik di luar KUHP, Cetakan Ketiga, Prenemedia Grup, Jakarta, 2019

Soerjono, Seokanto, Faktor-faktor yang mempengaruhi Penegakan Hukum, Rajawali Press, Jakarta, 1983.

Wahid, Abdul, et.al, Kejahatan Terorisme Persepektif Agama, Ham dan Hukum, PT. Raflika Aditama, Bandung, 2004.

Wibowo, Ari, Hukum Pidana Terorisme, Graha Ilmu, Yogyakarta, 2012.

\section{Makalah/Pidato/Wawancara}

Busjro Muqoddas, Indonesia Lawyer Club TV One: ISIS sudah di Kampung Melayu? Juni 2017.

\section{Peraturan Perundang-Undangan}

Undang-Undang Nomor 15 Tahun 2003 Tentang Pemebrantasan Tindak Pidana Teorisme, Lembaran Negara Republik Indonesia Tahun 2003, Tambahan Lembaran Negara RI Nomor RI Nomor 4284

Undang-Undang Nomor 5 Tahun 2018 Tentang Pemebrantasan Tindak Pidana Teorisme, Lembaran Negara Republik Indonesia Tahun 2018, Tambahan Lembaran Negara RI Nomor RI Nomor 6216

Undang-Undang Nomor 5 Tahun 1998 Tentang Pengesahan Konvensi Menentang Penyiksaan dan Perlakuan atau Penghukuman Lain Yang Kejam,Tidak Manusiawi atau Merendahkan Martabat Manusia, Lembaran Negara Republik Indonesia Tahun 1998, Tambahan Lembaran Negara RI Nomor RI Nomor 3783

Undang-Undang Nomor 8 Tahun 1981 Tentang Kitab-kitab Hukum Acara Pidana, Lembaran Negara Republik Indonesia Tahun 1981, Tambahan Lembaran Negara RI Nomor RI Nomor 3209

Undang-Undang Nomor 39 Tahun 1999 Tentang Hak Asasi Manusia, Lembaran Negara Republik Indonesia Tahun 1999, Tambahan Lembaran Negara RI Nomor RI Nomor 3886 